\title{
Evaluation of Irrigation-Drainage Scheme under Water Level Regulation Based on TOPSIS in Southern China
}

\author{
Yuanyuan $\mathrm{Li}^{1,2}$, Menghua Xiao ${ }^{2 *}$, Guanxi $\mathrm{Zhu}^{3}$, Yanbin $\mathrm{Li}^{1}$ \\ ${ }^{1}$ School of Water Conservancy, North China University of Water Resource and Electric Power, \\ Zhengzhou, 450045, P.R. China \\ ${ }^{2}$ Zhejiang Institute of Hydraulics and Estuary, Hangzhou, 310020, P.R. China \\ ${ }^{3}$ Zhongnan Engineering Corporation Limited, Changsha, 410014, China
}

Received: 11 March 2020

Accepted: 18 April 2020

\begin{abstract}
Paddy water management for saving water, maintaining high rice yield, reducing pollution and fertilizer maintenance has a great significance for the agriculture development in China. The aim of this study was to evaluate water level management schemes in all growth stages for flooding and drought paddy field based on the indicators of the yield, water use efficiency (WUE), the losses of ammonia nitrogen $\left(\mathrm{NH}_{4}^{+}-\mathrm{N}\right)$ and the total phosphorus (TP), and the available nitrogen (RAN) and available phosphorus (RAP) content in soil by using entropy weight TOPSIS model. The results showed that, rice yield, soil RAP and RAN had significant difference for flooding and drought treatments. As for WUE, water supply was favorable for higher WUE in the early growth stage of rice, and moderate drought could improve WUE in the late growth stage. With drought conditions, it could not only reduce water consumption, but also improve water use efficiency and yield. Also, the averaged nonpoint source pollution for drought treatments was higher than that for flooding treatments. Water leakage was crucial for yield production. TOPSIS modeling showed that, for flooding field, leakage intensity should be controlled at $4 \mathrm{~mm} \mathrm{~d}^{-1}$, in tillering stage, with flooding time lasting 5 days, and suitable flooding depth was $100 \mathrm{~mm}$; in jointing-booting and milkying stage, flooding time lasted 5 days, and suitable flooding depth was $250 \mathrm{~mm}$; for heading-flowering stage, flooding time lasted 7 days, and suitable flooding depth was $200 \mathrm{~mm}$; for drought paddy field, in tillering stage, drought time lasted 7 days, suitable drought depth was $-300 \mathrm{~mm}$; while in the other stages, drought time lasted 5 days, and suitable drought depth was $-600 \mathrm{~mm}$. With drought condition, $\mathrm{NH}_{4}^{+}-\mathrm{N}, \mathrm{NO}_{3}^{-}-\mathrm{N}$ and $\mathrm{TP}$ loss was $66.72 \%, 55.56 \%$ and $42.81 \%$, respectively lower than that for flooding treatments.
\end{abstract}

Keywords: TOPSIS model, water level control, paddy field, flooding and drought, irrigation-drainage technical indicators

*e-mail: menghuaxiao@aliyun.com 


\section{Introduction}

To ease the contradiction between water supply and demand, water-saving irrigation techniques of rice were widely studied [1,2]. China is the largest producer and consumer of synthetic fertilizers in the world, with the total nitrogen fertilizer consumption increasing from $2.16 \times 10^{10} \mathrm{~kg}$ in 2000 to $2.39 \times 10^{10} \mathrm{~kg}$ in 2017 , accounting for over one-third of the world's fertilizer consumption [3]. A large amount of nitrogen and phosphorus element entered into the ambient water bodies in the form of surface runoff, resulting in water eutrophication [4-6]. However, paddy field as a wetland can achieve water purification by maintaining proper water level in field surface for a certain number of days after fertilization or heavy rains. Therefore, controlled drainage technology in paddy field was paid highly attention worldwide [7, 8]. As a drainage pattern, controlled drainage is different from traditional drainage. With control facilities set at the drain outlet (open ditch or underground pipe), it implements effective management in accordance with the water condition of crop growth, farmland water level of drainage, and drainage duration $[9,10]$. Reasonable controlled drainage management in farmland is not only helpful for improving the water use efficiency of rainfall and irrigation but also can reduce the loss of nitrogen and phosphorus fertilizer. Thus, controlled drainage can effectively ease the chemical substances pollution in the surrounding water environment, and it also plays important role to control agricultural non-point source pollution. Therefore, it is of great significance to guide the practice of agriculture production by studying on the water level control schemes, grasping the drainage opportunity and searching the controlled drainage schemes which can not only reduce the non-point source pollution of nitrogen and phosphorus but also not reduce the rice yield. However, controlled drainage schemes optimization in the paddy field is a typical complicated nonlinear problem affected by many factors. This is because controlled drainage is a multi-objects system and single index size is very difficult to evaluate controlled-drainage schemes in paddy field. Therefore, the focus on controlled-drainage scheme optimization research is how to combine multiple evaluation indexes converting into the comprehensive evaluation of a single index, which can be more intuitive to achieve optimization in one-dimensional space. At present, the existing evaluation methods such as comprehensive index method, analytic hierarchy process, and fuzzy comprehensive evaluation method were used to optimize the controlled-drainage scheme [11, 12]. Since the dimension of each indicator is different, it is difficult to determine the weight problem and objectively reflect the data of each evaluation indicator by carrying digital information belt. On the contrary, it is easy to deviate from the goal of evaluation, and lack the structural evaluation of the contribution of evaluation indexes to the overall goal of the magnitude and the direction $[13,14]$. Therefore, this paper puts forward entropy weight TOPSIS model based on controlled drainage scheme evaluation in the paddy field to complete the process of reduction of high dimensional data and achieve multiple evaluation indicators converting into a comprehensive index. In the process of weight decisionmaking of this model, the entropy weight method is used to avoid disturbing of subjective factors, start from the measured data, make full use of the information of the data, and then determine the weight objectively. Thus the determination of the weight will be more reasonable. At present, the entropy weight method has been widely applied to the assessment of water environmental quality, water-saving benefit evaluation and optimization of irrigation scheme for making weight decision [15-18].

The innovation of this paper was shown as followed, four areas were involved in the evaluation indicator system of the paddy field irrigation and drainage scheme, they were the efficient use of water resources, economic efficiency, reduction of the nonpoint source pollution, and capacity of soil fertilizer retention. As for the efficient use of water resources factor, the water use efficiency was considered. As for the economic efficiency factor the rice yield was considered. For the reduction of the non-point source pollution factor, the ammonium nitrogen and total phosphorus were considered, and for the capacity of soil fertilizer retention, the available nitrogen and available phosphorus in soil was considered. This study focused on the conjunct impudence of efficient use of water resources, economic efficiency, reduction of the non-point source pollution and soil fertilizer retention capacity in paddy field controlled-drainage, and selected the representative water management schemes of flooding and drought paddy field in the year of 2013-2017, obtained the optimal water level management schemes of the paddy field in each growth stage. It is not only important to study technical indicators on controlled drainage in paddy field for controlling and improving the water quality, but also for saving water, reducing pollution, and maintaining fertilizer and high rice yield.

\section{Materials and Methods}

\section{Experimental Site}

This study was carried out in an experimental field in 2013-2017 at efficient irrigation and drainage and Environment of Agriculture water and soil of South area Key Laboratory of the Ministry of Education located in Jiangning Campus of Hohai University, Jiangsu Province of China. The region has a subtropical humid monsoon climate zone, with the average annual evaporation of $900 \mathrm{~mm}$, the yearly average temperature of $15.4^{\circ} \mathrm{C}$ and the maximum and minimum air temperatures are $43.0^{\circ} \mathrm{C}$ and $-14.0^{\circ} \mathrm{C}$, respectively. The mean annual rainfall is $1041 \mathrm{~mm}$ of which more than $60 \%$ of precipitation falls in the rainy season and the 
Table 1. Water control schemes in flooding paddy field in the year 2013-2017.

\begin{tabular}{|c|c|c|c|c|}
\hline Treatment & Tillering stage & Jointing-booting stage & Heading-flowering stage & Milkying stage \\
\hline FT1 & $120 \mathrm{~mm}(7 \mathrm{~d})$ & $-200 \mathrm{~mm}-20 \mathrm{~mm}$ & $-200 \mathrm{~mm}-20 \mathrm{~mm}$ & $-200 \mathrm{~mm}-20 \mathrm{~mm}$ \\
\hline FT2 & $100 \mathrm{~mm}(5 \mathrm{~d})$ & $-200 \mathrm{~mm}-20 \mathrm{~mm}$ & $-200 \mathrm{~mm}-20 \mathrm{~mm}$ & $-200 \mathrm{~mm}-20 \mathrm{~mm}$ \\
\hline FT3 & $100 \mathrm{~mm}(7 \mathrm{~d})$ & $-200 \mathrm{~mm}-20 \mathrm{~mm}$ & $-200 \mathrm{~mm}-20 \mathrm{~mm}$ & $-200 \mathrm{~mm}-20 \mathrm{~mm}$ \\
\hline FT4 & $120 \mathrm{~mm}\left(2 \mathrm{~mm} \mathrm{~d}^{-1} 10 \mathrm{~d}\right)$ & $-300 \mathrm{~mm}-30 \mathrm{~mm}$ & $-300 \mathrm{~mm}-30 \mathrm{~mm}$ & $-300 \mathrm{~mm}-30 \mathrm{~mm}$ \\
\hline FT5 & $120 \mathrm{~mm}\left(4 \mathrm{~mm} \mathrm{~d}^{-1} 10 \mathrm{~d}\right)$ & $-300 \mathrm{~mm}-30 \mathrm{~mm}$ & $-300 \mathrm{~mm}-30 \mathrm{~mm}$ & $-300 \mathrm{~mm}-30 \mathrm{~mm}$ \\
\hline FJ1 & $200 \mathrm{~mm}-20 \mathrm{~mm}$ & $150 \mathrm{~mm}(10 \mathrm{~d})$ & $-200 \mathrm{~mm}-20 \mathrm{~mm}$ & $-200 \mathrm{~mm}-20 \mathrm{~mm}$ \\
\hline FJ2 & $200 \mathrm{~mm}-20 \mathrm{~mm}$ & $250 \mathrm{~mm}(5 \mathrm{~d})$ & $-200 \mathrm{~mm}-20 \mathrm{~mm}$ & $-200 \mathrm{~mm}-20 \mathrm{~mm}$ \\
\hline FJ3 & $200 \mathrm{~mm}-20 \mathrm{~mm}$ & $250 \mathrm{~mm}(7 \mathrm{~d})$ & $-200 \mathrm{~mm}-20 \mathrm{~mm}$ & $-200 \mathrm{~mm}-20 \mathrm{~mm}$ \\
\hline FJ4 & $-300 \mathrm{~mm}-30 \mathrm{~mm}$ & $250 \mathrm{~mm}\left(2 \mathrm{~mm} \mathrm{~d}^{-1} 10 \mathrm{~d}\right)$ & $-300 \mathrm{~mm}-30 \mathrm{~mm}$ & $-300 \mathrm{~mm}-30 \mathrm{~mm}$ \\
\hline FJ5 & $-300 \mathrm{~mm}-30 \mathrm{~mm}$ & $250 \mathrm{~mm}\left(4 \mathrm{~mm} \mathrm{~d}^{-1} 10 \mathrm{~d}\right)$ & $-300 \mathrm{~mm}-30 \mathrm{~mm}$ & $-300 \mathrm{~mm}-30 \mathrm{~mm}$ \\
\hline FH1 & $-200 \mathrm{~mm}-20 \mathrm{~mm}$ & $-200 \mathrm{~mm}-20 \mathrm{~mm}$ & $200 \mathrm{~mm}(7 \mathrm{~d})$ & $-200 \mathrm{~mm}-20 \mathrm{~mm}$ \\
\hline FH2 & $-200 \mathrm{~mm}-20 \mathrm{~mm}$ & $-200 \mathrm{~mm}-20 \mathrm{~mm}$ & $250 \mathrm{~mm}(5 \mathrm{~d})$ & $-200 \mathrm{~mm}-20 \mathrm{~mm}$ \\
\hline FH3 & $-200 \mathrm{~mm}-20 \mathrm{~mm}$ & $-200 \mathrm{~mm}-20 \mathrm{~mm}$ & $250 \mathrm{~mm}(7 \mathrm{~d})$ & $-200 \mathrm{~mm}-20 \mathrm{~mm}$ \\
\hline FH4 & $-300 \mathrm{~mm}-30 \mathrm{~mm}$ & $-300 \mathrm{~mm}-30 \mathrm{~mm}$ & $250 \mathrm{~mm}\left(2 \mathrm{~mm} \mathrm{~d}^{-1} 10 \mathrm{~d}\right)$ & $-300 \mathrm{~mm}-30 \mathrm{~mm}$ \\
\hline FH5 & $-300 \mathrm{~mm}-30 \mathrm{~mm}$ & $-300 \mathrm{~mm}-30 \mathrm{~mm}$ & $250 \mathrm{~mm}\left(4 \mathrm{~mm} \mathrm{~d}^{-1} 10 \mathrm{~d}\right)$ & $-300 \mathrm{~mm}-30 \mathrm{~mm}$ \\
\hline FM1 & $-200 \mathrm{~mm}-20 \mathrm{~mm}$ & $-200 \mathrm{~mm}-20 \mathrm{~mm}$ & $-200 \mathrm{~mm}-20 \mathrm{~mm}$ & $200 \mathrm{~mm}(7 \mathrm{~d})$ \\
\hline FM2 & $-200 \mathrm{~mm}-20 \mathrm{~mm}$ & $-200 \mathrm{~mm}-20 \mathrm{~mm}$ & $-200 \mathrm{~mm}-20 \mathrm{~mm}$ & $250 \mathrm{~mm}(5 \mathrm{~d})$ \\
\hline FM3 & $-200 \mathrm{~mm}-20 \mathrm{~mm}$ & $-200 \mathrm{~mm}-20 \mathrm{~mm}$ & $-200 \mathrm{~mm}-20 \mathrm{~mm}$ & $250 \mathrm{~mm}(7 \mathrm{~d})$ \\
\hline FM4 & $-300 \mathrm{~mm}-30 \mathrm{~mm}$ & $-300 \mathrm{~mm}-30 \mathrm{~mm}$ & $-300 \mathrm{~mm}-30 \mathrm{~mm}$ & $250 \mathrm{~mm}\left(2 \mathrm{~mm} \mathrm{~d}^{-1} 10 \mathrm{~d}\right)$ \\
\hline FM5 & $-300 \mathrm{~mm}-30 \mathrm{~mm}$ & $-300 \mathrm{~mm}-30 \mathrm{~mm}$ & $-300 \mathrm{~mm}-30 \mathrm{~mm}$ & $250 \mathrm{~mm}\left(4 \mathrm{~mm} \mathrm{~d}^{-1} 10 \mathrm{~d}\right)$ \\
\hline
\end{tabular}

Note: 1 . Positive value is flooding depth, while negative value is the length from field surface to underground water level.

2. The numbers in parentheses are water leakage amount and flooding days' duration.

precipitation is concentrated in the months from May to September. The number of frost-free days is 220 per year. The soil in the area is a typical permeable paddy soil, formed on loess deposits, with loamy clay. The area has been 5 years of rice-wheat rotation system. There are 32 fixed lysimeter plots (28 with closed bottom, 4 without bottom) with specifications for the length $\times$ width $\times$ depth $=2.5 \mathrm{~m} \times 2 \mathrm{~m} \times 2 \mathrm{~m}$. The lysimeters are divided into two groups, each group of 16. Underground corridors and underground equipment room are built between the two groups and mobile canopy is equipped on the ground. The irrigation system is automatic irrigation system controlled by the host-electromagnetic valve. The topsoil $(0-30 \mathrm{~cm})$ in lysimeter with $\mathrm{pH}$ value of 6.97 contained $2.40 \%$ of soil organic matter, $0.9048 \mathrm{~g} \mathrm{~kg}^{-1}$ of total nitrogen, $27.65 \mathrm{mg} \mathrm{kg}{ }^{-1}$ of available nitrogen, $0.32 \mathrm{~g} \mathrm{~kg}^{-1}$ of total phosphorus, and $12.5 \mathrm{mg} \mathrm{kg}^{-1}$ of available phosphorus.

\section{Experimental Design}

The rice experienced re-greening stage, tillering stage, jointing and booting stage, heading and flowering stage, milk stage and ripening stage during the whole cultivation period after rice seedlings transplanted to the field. According to the characteristics of rice growth stages, we chose tillering stage, jointing and booting stage, heading and flowering stage and milk stage to carry out experiment under different flooding conditions from 2013 to 2017. Treatments were set up in the lysimeter plots with closed bottoms; each treatment was replicated four times during experiments. Water control schemes in flooding experiment were listed in Table 1. Water control was conducted to satisfy the leakage set via irrigation and drainage during flooding periods at each growth stage, while water management conducted complying with the requirement of shallow and wetting irrigation at the other days of each stage.

The drought treatment tests were designed for 12 treatments (Table 2). In each growth stage, the water level control duration was different. Water level control followed the principle of different starting time but the same ending time. The groundwater level control was consistent according to the control standard, groundwater was recharged through the standpipe, and field surface irrigation should be avoided. After the 
Table 2. Water control schemes in drought paddy field in the year 2013-2017.

\begin{tabular}{|c|c|c|c|c|}
\hline Treatment & Tillering satge & Jointing-heading stage & Heading-flowering stage & Milkying stage \\
\hline DT1 & $300 \mathrm{~mm}(5 d)$ & $-300 \mathrm{~mm}-30 \mathrm{~mm}$ & $-300 \mathrm{~mm}-30 \mathrm{~mm}$ & $-300 \mathrm{~mm}-30 \mathrm{~mm}$ \\
\hline DT2 & $-300 \mathrm{~mm}(7 \mathrm{~d})$ & $-300 \mathrm{~mm}-30 \mathrm{~mm}$ & $-300 \mathrm{~mm}-30 \mathrm{~mm}$ & $-300 \mathrm{~mm}-30 \mathrm{~mm}$ \\
\hline DT3 & $-600 \mathrm{~mm}(5 d)$ & $-300 \mathrm{~mm}-30 \mathrm{~mm}$ & $-300 \mathrm{~mm}-30 \mathrm{~mm}$ & $-300 \mathrm{~mm}-30 \mathrm{~mm}$ \\
\hline DJ1 & $-200 \mathrm{~mm}-20 \mathrm{~mm}$ & $-300 \mathrm{~mm}(5 d)$ & $-300 \mathrm{~mm}-30 \mathrm{~mm}$ & $-300 \mathrm{~mm}-30 \mathrm{~mm}$ \\
\hline DJ2 & $-200 \mathrm{~mm}-20 \mathrm{~mm}$ & $-300 \mathrm{~mm}(7 \mathrm{~d})$ & $-300 \mathrm{~mm}-30 \mathrm{~mm}$ & $-300 \mathrm{~mm}-30 \mathrm{~mm}$ \\
\hline DJ3 & $-200 \mathrm{~mm}-20 \mathrm{~mm}$ & $-600 \mathrm{~mm}(5 d)$ & $-300 \mathrm{~mm}-30 \mathrm{~mm}$ & $-300 \mathrm{~mm}-30 \mathrm{~mm}$ \\
\hline DH1 & $-200 \mathrm{~mm}-20 \mathrm{~mm}$ & $-300 \mathrm{~mm}-30 \mathrm{~mm}$ & $-300 \mathrm{~mm}(5 d)$ & $-300 \mathrm{~mm}-30 \mathrm{~mm}$ \\
\hline DH2 & $-200 \mathrm{~mm}-20 \mathrm{~mm}$ & $-300 \mathrm{~mm}-30 \mathrm{~mm}$ & $-300 \mathrm{~mm}(7 \mathrm{~d})$ & $-300 \mathrm{~mm}-30 \mathrm{~mm}$ \\
\hline DH3 & $-200 \mathrm{~mm} 0-20 \mathrm{~mm}$ & $-300 \mathrm{~mm}-30 \mathrm{~mm}$ & $-600 m m(5 d)$ & $-300 \mathrm{~mm}-30 \mathrm{~mm}$ \\
\hline DM1 & $-200 \mathrm{~mm}-20 \mathrm{~mm}$ & $-300 \mathrm{~mm}-30 \mathrm{~mm}$ & $-300 \mathrm{~mm}-30 \mathrm{~mm}$ & $-300 \mathrm{~mm}(5 d)$ \\
\hline DM2 & $-200 \mathrm{~mm}-20 \mathrm{~mm}$ & $-300 \mathrm{~mm}-30 \mathrm{~mm}$ & $-300 \mathrm{~mm}-30 \mathrm{~mm}$ & $-300 \mathrm{~mm}(7 \mathrm{~d})$ \\
\hline DM3 & $-200 \mathrm{~mm}-20 \mathrm{~mm}$ & $-300 \mathrm{~mm}-30 \mathrm{~mm}$ & $-300 \mathrm{~mm}-30 \mathrm{~mm}$ & $-600 \mathrm{~mm}(5 d)$ \\
\hline
\end{tabular}

Note: 1.Positive value is flooding depth, while negative value is the length from field surface to underground water level.

2.The numbers in parentheses is drought days' duration.

water level control, it should be irrigated to appropriate upper limit. Three different does of inorganic fertilizer was supplied at the time of seeding and during the cultivation. Only the basal fertilizers were incorporated to the surface soil while the other fertilizations were surface applied. Compound fertilizer $\left(\mathrm{N}: \mathrm{P}_{2} \mathrm{O}_{5}\right.$ : $\mathrm{K}_{2} \mathrm{O}$ as $15: 15: 15 \%$ ) was chosen for basal fertilizer, $1200 \mathrm{~kg} \mathrm{ha}^{-1}$. Urea (nitrogen content 46.4\%), $647 \mathrm{~kg} \mathrm{ha}^{-1}$ was applied as tillering and panicle fertilizer.

\section{Indicators and Measurements}

Grain yield in each treatment was calculated as the following equation:

$$
Y=E P N \times S P N \times S S R \times T G W
$$

...where, $Y$ is grain yield, $\mathrm{kg} \mathrm{ha}^{-1} ; E P N$ is effective panicles number per unit area; $S P N$ is spikelet number per panicle; SSR is seed setting rate, \%; TGW is 1000 -grain weight, $\mathrm{g}$.

According to the requirements of irrigation test specification, 5 points were randomly selected from each test plot before rice harvest, with the measurement of the number of panicles, real grain and imperfect grain. Each test plot samples were taken twice using iron frame with specifications for the length $\times$ width $=0.5 \mathrm{~m} \times 0.5 \mathrm{~m}$, measuring spike number of the Iron frame; After harvest, randomly selecting 1000 real grains per point, and then weighing thousand seed weight.

Water use efficiency (WUE) is the unit output by the unit water consumption. In this study, the amount of rainwater utilization is the volume of evapotranspiration for paddy field. The amount of evapotranspiration of each treatment can be calculated based on the water balance principle as follows:

$$
E T_{t}=P_{t}+I_{t}+W_{t-1}+W_{t}-D_{t}
$$

...where $E T$ is the volume of evapotranspiration, $\mathrm{mm} ; P$ is the volume of precipitation, $\mathrm{mm}$, and it was recorded daily by an automatic weather station (ICT, Australia); $I$ is the volume of irrigation water, $\mathrm{mm}$, and the volumes were recorded by water meters installed on the pipes for each plot; $W$ is the flooding depth or the soil water content in the root zone, $\mathrm{mm}$. The levels of soil moistures for the treatments were measured by a time domain reflectometer (TDR), and pond water depths were measured by vertical rulers; $t$ is the day of determination. $D$ is the volume of drainage and underlying root leakage, $\mathrm{mm}$.

$\mathrm{NH}_{4}^{+}{ }^{-} \mathrm{N}$ was determined by the Nessler's reagent coforimetric method, TP was measured in unfiltered samples according to indophenol blue method. Available nitrogen (RAN) was measured through base diffusion method, and available phosphorus (RAP) was measured through $\mathrm{NH}_{4} \mathrm{~F}-\mathrm{HCl}$ method.

\section{Water Level Control Mode}

In this paper, reasonable irrigation and drainage scheme of rice was studied in the field scale, optimal water level control schemes of each growth stage were elected from the 5 and 3 treatments respectively in flooding and drought paddy field in each growth stage, which provided the basis for paddy field irrigation and drainage practices. Using entropy weight TOPSIS model, four areas were involved in the evaluation indicator system of the paddy field irrigation and drainage 
Table 3. Rice yield and WUE under different water level regulations.

\begin{tabular}{|c|c|c|c|c|c|c|c|}
\hline Treatment & $\begin{array}{c}\text { Actual Yield } \\
\left(\mathrm{kg} \mathrm{hm}^{-1}\right)\end{array}$ & $\begin{array}{c}\text { Irrigation Amount } \\
(\mathrm{mm})\end{array}$ & $\begin{array}{c}\text { Water Consumption } \\
(\mathrm{mm})\end{array}$ & $\begin{array}{c}\text { Evapotranspiration } \\
(\mathrm{mm})\end{array}$ & $\begin{array}{c}\mathrm{WUE}_{\mathrm{IR}} \\
\left(\mathrm{kg} \mathrm{m}^{-3}\right)\end{array}$ & $\begin{array}{c}\mathrm{WUE}_{\mathrm{WU}} \\
\left(\mathrm{kg} \mathrm{m}^{-3}\right)\end{array}$ & $\begin{array}{c}\mathrm{WUE}_{\mathrm{ET}} \\
\left(\mathrm{kg} \mathrm{m}^{-3}\right)\end{array}$ \\
\hline Flooding & 7143.6 & 840.3 & 1473.4 & 584.3 & 0.85 & 0.48 & 1.22 \\
\hline Drought & 6856.4 & 235.6 & 814.5 & 425.7 & 2.91 & 0.84 & 1.61 \\
\hline
\end{tabular}

scheme, they were efficient use of water resources, economic efficiency, reduction of the non-point source pollution, and capacity of soil fertilizer retention. The evaluating indicators of them were the WUE, yield, loss of $\mathrm{NH}_{4}^{+}-\mathrm{N}$ and $\mathrm{TP}$ in paddy water, and the RAN and RAP content in soil respectively. This method is used to comprehensively evaluate the project of controlled drainage in paddy fields for solving the incompatibility of evaluation indicators. Additionally, it can reflect the contribution of each evaluation indicator to the overall evaluation target. By using the entropy weight TOPSIS model, high dimension data was converted into low dimension space.

\section{Results and Discussion}

\section{Rice Yield and WUE under Different Water Level Regulations}

As shown in Table 3, the actual rice yield for flooding and drought treatments were $7143.6 \mathrm{~kg} \mathrm{hm}^{-2}$ and $6856.4 \mathrm{~kg} \mathrm{hm}^{-2}$, respectively. It was $4.0 \%$ lower for drought treatment compared to flooding treatment. The WUE was calculated according to irrigation water amount, water consumption and evapotranspiration during the whole growth stage. The WUE on basis of irrigation water amount, water consumption and evapotranspiration for flooding treatment was $0.85 \mathrm{~kg} \mathrm{~m}^{-3}, 0.46 \mathrm{~kg} \mathrm{~m}^{-3}$ and $1.22 \mathrm{~kg} \mathrm{~m}^{-3}$, while for drought treatments they were $2.91 \mathrm{~kg} \mathrm{~m}^{-3}$, $0.84 \mathrm{~kg} \mathrm{~m}^{-3}, 2.11 \mathrm{~kg} \mathrm{~m}^{-3}$, respectively, which illustrated that droughting could reduce water consumption, meantime, it also improved water use efficiency and yield.
The rice yield and WUE under different water level regulations were shown in Fig. 1 and Fig. 2. Taking the rice yield in tillering stage for example, it was clear that there was significant difference for flooding and drought treatments. There was no significance for yield between FT1, FT2 and FT3, while there was significant difference between the above three treatments and FT4, FT5. It illustrated that water leakage was crucial for yield production at this growth stage. As for WUE, it was lowest for DT1 and DJ1 in tillering and jointingbooting stages, respectively, while in milk and headingflowering stage, it was lowest for FH4 and FM5 treatment. It explained that enough water supply was favorable for higher WUE in the early growth stage of rice, and moderate drought could improve WUE in the late growth stage.

\section{$\mathrm{N}$ and P Loss under Different Water Level Regulations}

The loss of nitrogen and phosphorus under different drainage scheme was shown in Table 4. It was clear that the main form of nitrogen loss was $\mathrm{NH}_{4}^{+}-\mathrm{N}$, while the proportion for $\mathrm{NO}_{3}^{-}-\mathrm{N}$ was small. The averaged $\mathrm{NH}_{4}^{+}-\mathrm{N}$ loss for flooding treatment was $5.80 \mathrm{~kg} \mathrm{hm}^{-2}$, accounting for $53.70 \%$ of total nitrogen loss, while for drought treatment it was $1.93 \mathrm{~kg} \mathrm{hm}^{-2}$, accounting for $53.61 \%$. The $\mathrm{NH}_{4}^{+}-\mathrm{N}$ loss for flooding treatment was $3.87 \mathrm{~kg} \mathrm{hm}^{-2}$ less than that for drought treatment, and the reduction range was $66.72 \%$. As for $\mathrm{NO}_{3}^{-}-\mathrm{N}$ loss, the averaged $\mathrm{NO}_{3}^{-}-\mathrm{N}$ loss for flooding treatment was $0.63 \mathrm{~kg} \mathrm{hm}$, accounting for $5.83 \%$ of total nitrogen loss, while for drought treatment it was $0.28 \mathrm{~kg} \mathrm{hm}^{-2}$, accounting for $7.78 \%$. The $\mathrm{NO}_{3}{ }^{-} \mathrm{N}$ loss for flooding treatment was $0.35 \mathrm{~kg} \mathrm{hm}^{-2}$ less than that for

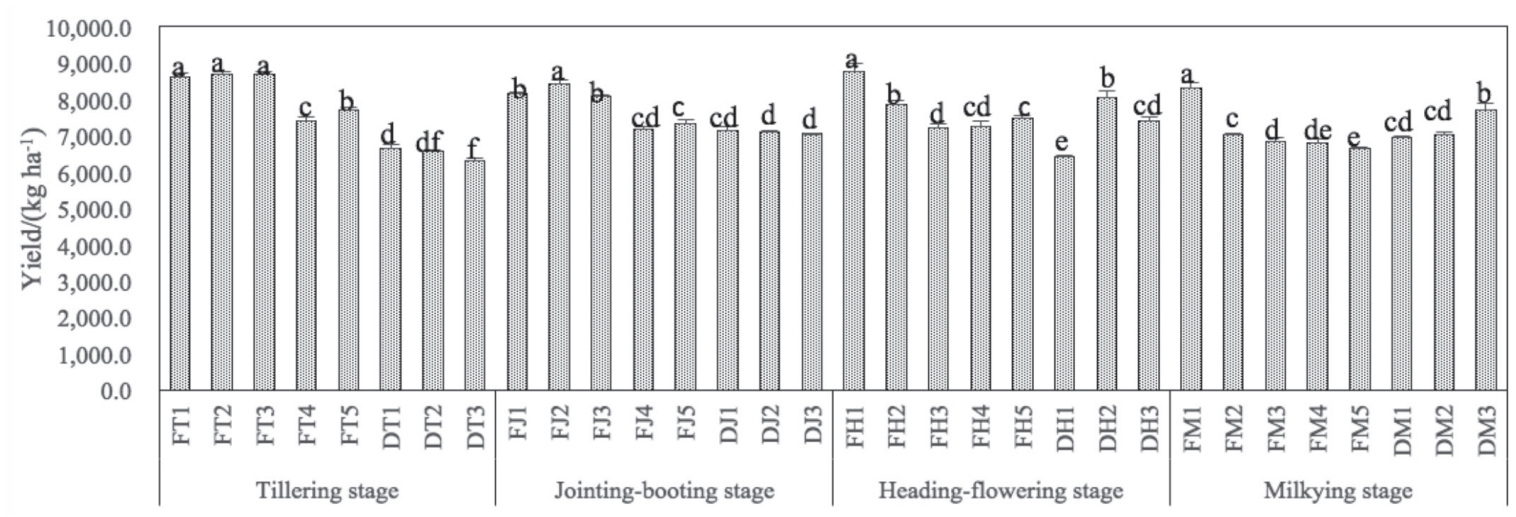

Fig. 1. Rice yield under different water level treatments. 


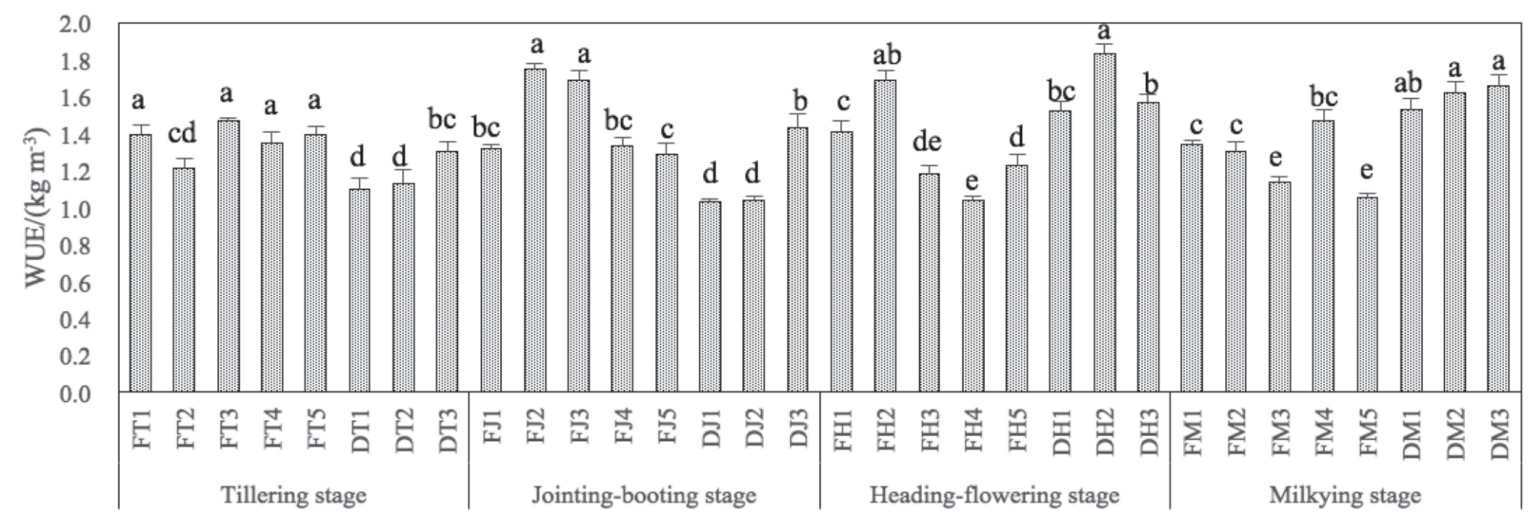

Fig. 2. Water ues efficiency under different water level treatments.

drought treatment, and the reduction range was $55.56 \%$. The $\mathrm{NH}_{4}^{+}-\mathrm{N}$ loss in paddy field drainage was affected by fertilization and irrigation management schemes, and the change law was basically in accordance to total loss change. With the same fertilizer level, the treatment for drought treatment could obviously reduce the $\mathrm{NH}_{4}^{+}-\mathrm{N}$ loss. The $\mathrm{NO}_{3}^{-}-\mathrm{N}$ loss was maintained at a low level, which was due for the lower $\mathrm{NO}_{3}^{-}-\mathrm{N}$ content in soil. Since the $\mathrm{NO}_{3}^{-}-\mathrm{N}$ in drainage was mainly from wheat season remaining, precipitation and irrigation, the $\mathrm{NO}_{3}^{-}-\mathrm{N}$ content in rice season was lower. That was because of the lower soil oxygen content of the soil, which resulted in nitrification rate decreasing, thus only a little $\mathrm{NH}_{4}^{+}-\mathrm{N}$ converting to $\mathrm{NO}_{3}^{-}-\mathrm{N}$.

The average total phosphorus loss for flooding treatment was $2.85 \mathrm{~kg} \mathrm{hm}^{-2}$, accounting for $5.70 \%$ of the total phosphorus fertilizer application. For drought treatment, it was $1.63 \mathrm{~kg} \mathrm{hm}^{-2}$, accounting for $3.26 \%$, which illustrated TP loss could be reduced under drought treatment. In this experimental site, phosphorus fertilizer was one-time applied as basal fertilizer, thus field drainage should be avoided for reducing phosphorus loss.

From the above results, $\mathrm{NH}_{4}^{+}-\mathrm{N}, \mathrm{NO}_{3}^{-}-\mathrm{N}$ and TP loss for drought treatment was $3.87 \mathrm{~kg} \mathrm{hm}^{-2}, 0.35 \mathrm{~kg} \mathrm{hm}^{-2}$ and $1.22 \mathrm{~kg} \mathrm{hm}^{-2}$ lower than that for flooding treatment, and the reducing range was $66.72 \%, 55.56 \%$ and $42.81 \%$, respectively.

In Fig. 3, it can be seen that the average nonpoint source pollution for drought treatments was higher than that for flooding treatments. For flooding treatments, TP account for a small proportion of nonpoint source pollution, while it account for a large proportion for drought treatments. It can be concluded that enough water could increase $\mathrm{NH}_{4}{ }^{+} \mathrm{N}$ loss, and with drought treatment TP loss also increased in every growth stage.

\section{RAP and RAN Content in Soil under Different Water Level Regulations}

From Fig. 4 we can see clearly that the water level regulation had a significant difference on soil RAP and RAN, while the RAP and RAN content in soil showed no significance under different water level control for both drought and flooding treatments. For the treatments under drought conditions, the soil available nitrogen and phosphorus content were extremely higher than that under flooding condition. It explained that drought treatment was favorable for soil available nutrients accumulation.

\section{Entropy TOPSIS Multi-Objective Decision-Making Model}

Entropy is an important concept in thermodynamics, which performs the disordered state and disorder degree of material system. The more disordered the system is, the bigger the entropy is, on the contrary, the more orderly the system is, the smaller the entropy is. Introducing the concept of entropy into the information theory, the objective is to represent uncertainty degree of a signal state source of information. The basic ideas of entropy weight TOPSIS model of multi-objective decision are as follows: Firstly, the ideal and negative ideal solutions of weighted standard evaluation index value are determined by constructing decision matrix. Secondly, the Euclidean distance between evaluation scheme and ideal and negative ideal solution calculate are calculated. Thirdly, the relative closeness degree

Table 4. N and P loss under different water level regulations.

\begin{tabular}{|c|c|c|c|c|c|c|}
\hline Treatment & $\begin{array}{c}\mathrm{NH}_{4}^{+}-\mathrm{N} \text { loss } \\
\left(\mathrm{kg} \mathrm{hm}^{-2}\right)\end{array}$ & $\begin{array}{c}\text { Proportion of } \mathrm{TP} \\
\text { loss (\%) }\end{array}$ & $\begin{array}{c}\mathrm{NO}_{3}^{-}-\mathrm{N} \text { loss } \\
\left(\mathrm{kg} \mathrm{hm}^{-2}\right)\end{array}$ & $\begin{array}{c}\text { Proportion of TP } \\
\text { loss (\%) }\end{array}$ & $\begin{array}{c}\mathrm{TP} \text { loss } \\
\left(\mathrm{kg} \mathrm{hm}^{-2}\right)\end{array}$ & $\begin{array}{c}\text { Proportion of P fertilizer } \\
\text { application (\%) }\end{array}$ \\
\hline Flooding & 5.80 & 53.70 & 0.63 & 5.83 & 2.85 & 5.70 \\
\hline Drought & 1.93 & 53.61 & 0.28 & 7.78 & 1.63 & 3.26 \\
\hline
\end{tabular}




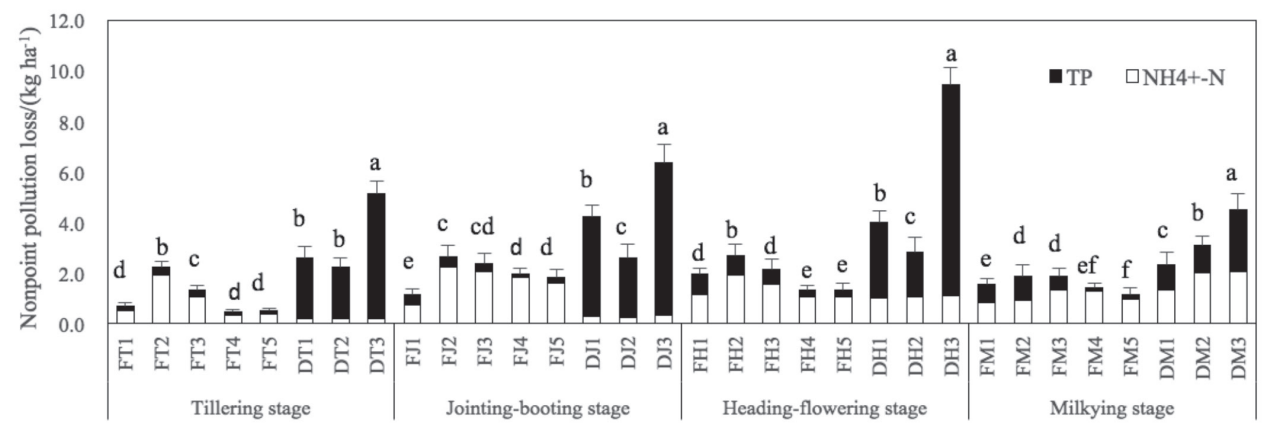

Fig. 3. Nitrogen and phosphorus loss under different water level treatments.

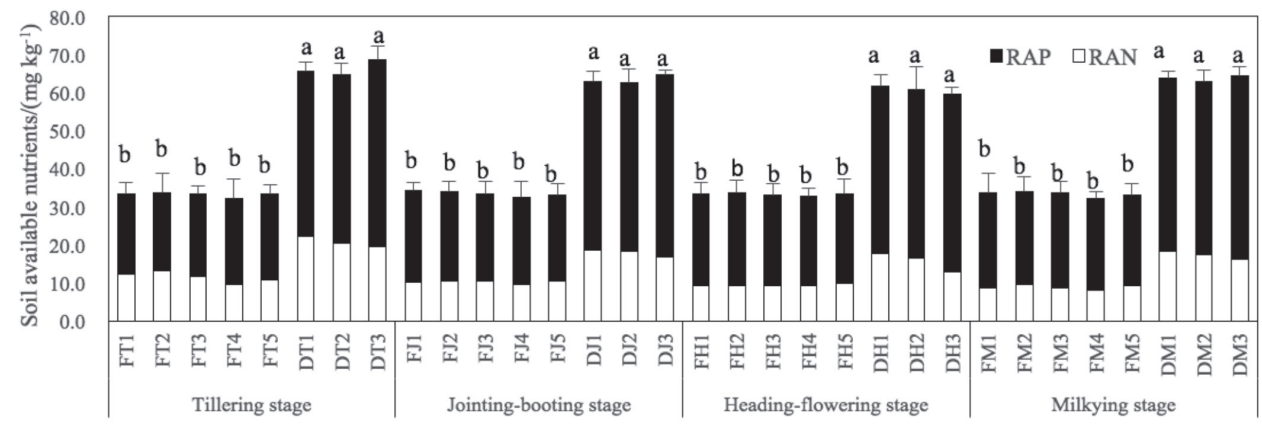

Fig. 4. RAP and RAN content in soil under different water level treatments.

between evaluation schemes and the ideal solution are determined. Finally, the scheme which is closest to the ideal solution is selected as the optimal decision scheme.

\section{Determination of the Evaluation System}

Paddy field irrigation-drainage scheme evaluation indicator system mainly involved four aspects which were the efficient use of water resources, economic benefits, non-point source pollution, and soil fertility. The efficient use of water resources mainly considered the rice water use efficiency; economic benefits mainly considered the grain yield; reducing non-point source pollution mainly considered two indicators of $\mathrm{NH}_{4}^{+}-\mathrm{N}$ and TP losses; soil fertility mainly considered two indexes of RAN and RAP content. The evaluation indicator values of each treatment were listed in Table 5 and Table 6 respectively in flooding and drought paddy field. Lv et al. [19] used projection pursuit model to analyze the data of the year 2013 for researching controlled drainage schemes of the whole growth period, only focusing on environmental effect on controlled-drainage, but not on the water level management scheme optimization of different growth stages. In this paper, it added the water use efficiency, the leakage intensity and the available nitrogen and available phosphorus in soil to the indicator system, the environment factor considered the ammonium nitrogen and total phosphorus in paddy water, which is because nitrate nitrogen is not stable in the paddy field water.

\section{Water Level Program in Flooding Paddy Field}

At the tillering stage, for example, the modeling and solving steps are as follows:

Step 1: In order to evaluate the water level control schemes of flooded rice tests from 2013 to 2017 comprehensively, the yield, WUE, pollution load indicators of $\mathrm{NH}_{4}^{+}-\mathrm{N}$ and TP losses produced by paddy field drainage and soil fertilizer indicator of RAN and RAP were selected as evaluation factors to build an initial matrix named as [Y] (Fig. 5).

Step 2: According to the principle that the bigger yield, WUE, RAN and RAP the better and the smaller the pollution load index of $\mathrm{NH}_{4}^{+}-\mathrm{N}$ and TP losses produced by drainage the better, we can build a standardized decision matrix named as [R] (Fig. 6).

Step 3: Calculate the weight of all the indicators according to the definition of entropy weight, that is wj we can get the entropy: $\mathrm{E}=(\mathrm{e} 1, \mathrm{e} 2, \mathrm{e} 3, \mathrm{e} 4, \mathrm{e} 5$, e6) $=(0.7985,0.8456,0.8567,0.7739,0.8222,0.8209)$. The entropy weight: $\mathrm{W}=(\mathrm{w} 1, \mathrm{w} 2, \mathrm{w} 3, \mathrm{w} 4 \mathrm{w} 5, \mathrm{w} 6)=$ (0.1844, 0.1413, 0.1411, 0.2068, 0.1626, 0.1638).

Step 4: Built a standardized weighted decision matrix that was called $[\mathrm{Z}]$, and $[\mathrm{Z}]=(\mathrm{zij})$, where $\mathrm{zij}=w j \times$ rij. We can get the value of $[Z]$ (Fig.3) as follows.

Step 5: Determine the ideal solution named $\mathrm{x}^{+}$ and negative ideal solution named $\mathrm{x}-$. Among them, if it is an income indicators which is the greater the 
Table 5. The evaluation indicator values of each treatment in flooding paddy field.

\begin{tabular}{|c|c|c|c|c|c|c|}
\hline Treatment & $\begin{array}{c}\text { Yield } \\
\left(\mathrm{kg} \mathrm{m}^{-3}\right)\end{array}$ & $\begin{array}{c}\text { WUE } \\
\left(\mathrm{kg} \mathrm{m}^{-3}\right)\end{array}$ & $\begin{array}{l}\mathrm{NH}_{4}^{+}-\mathrm{N} \\
\left(\mathrm{kg} \mathrm{ha}^{-1}\right)\end{array}$ & $\begin{array}{c}\mathrm{TP} \\
\left(\mathrm{kg} \mathrm{ha}^{-1}\right)\end{array}$ & $\begin{array}{c}\text { RAN } \\
\left(\mathrm{mg} \mathrm{kg}^{-1}\right)\end{array}$ & $\begin{array}{c}\text { RAP } \\
\left(\mathrm{mg} \mathrm{kg}^{-1}\right)\end{array}$ \\
\hline FT1 & 8592 & 1.39 & 0.512 & 0.199 & 12.18 & 21.23 \\
\hline FT2 & 8673 & 1.21 & 1.903 & 0.330 & 13.24 & 20.34 \\
\hline FT3 & 8685 & 1.47 & 1.050 & 0.253 & 11.54 & 21.73 \\
\hline FT4 & 7406 & 1.35 & 0.347 & 0.095 & 9.43 & 22.72 \\
\hline FT5 & 7718 & 1.39 & 0.355 & 0.137 & 10.82 & 22.51 \\
\hline FJ1 & 8154 & 1.32 & 0.733 & 0.410 & 10.23 & 24.12 \\
\hline FJ2 & 8409 & 1.75 & 2.225 & 0.420 & 10.43 & 23.43 \\
\hline FJ3 & 8072 & 1.69 & 2.050 & 0.304 & 10.36 & 22.89 \\
\hline FJ4 & 7190 & 1.33 & 1.811 & 0.169 & 9.41 & 23.12 \\
\hline FJ5 & 7330 & 1.29 & 1.615 & 0.226 & 10.3 & 22.73 \\
\hline FH1 & 8750 & 1.41 & 1.149 & 0.800 & 9.32 & 23.97 \\
\hline FH2 & 7850 & 1.69 & 1.912 & 0.783 & 9.15 & 24.32 \\
\hline FH3 & 7222 & 1.18 & 1.554 & 0.570 & 9.26 & 23.89 \\
\hline FH4 & 7243 & 1.04 & 1.044 & 0.269 & 9.12 & 23.71 \\
\hline FH5 & 7477 & 1.23 & 1.048 & 0.268 & 9.70 & 23.54 \\
\hline FM1 & 8320 & 1.34 & 0.848 & 0.689 & 8.78 & 24.93 \\
\hline FM2 & 7035 & 1.30 & 1.502 & 0.974 & 9.53 & 24.34 \\
\hline FM3 & 6837 & 1.14 & 1.308 & 0.575 & 8.69 & 24.85 \\
\hline FM4 & 6807 & 1.47 & 1.258 & 0.152 & 8.04 & 23.92 \\
\hline FM5 & 6638 & 1.05 & 0.957 & 0.173 & 9.31 & 23.75 \\
\hline
\end{tabular}

Table 6. The evaluation indicator values of each treatment in drought paddy field.

\begin{tabular}{|c|c|c|c|c|c|c|}
\hline Treatment & $\begin{array}{c}\text { Yield } \\
\left(\mathrm{kg} \mathrm{m}^{-3}\right)\end{array}$ & $\begin{array}{l}\text { WUE } \\
\left(\mathrm{kg} \mathrm{m}^{-3}\right)\end{array}$ & $\begin{array}{l}\mathrm{NH}_{4}^{+}-\mathrm{N} \\
\left(\mathrm{kg} \mathrm{ha}^{-1}\right)\end{array}$ & $\begin{array}{c}\text { TP } \\
\left(\mathrm{kg} \mathrm{ha}^{-1}\right)\end{array}$ & $\begin{array}{c}\text { RAN } \\
\left(\mathrm{mg} \mathrm{kg}^{-1}\right)\end{array}$ & $\begin{array}{c}\text { RAP } \\
\left(\mathrm{mg} \mathrm{kg}^{-1}\right)\end{array}$ \\
\hline DT1 & 6658 & 1.1 & 0.189 & 2.421 & 22.1 & 43.3 \\
\hline DT2 & 6562 & 1.13 & 0.179 & 2.069 & 20.4 & 44.3 \\
\hline DT3 & 6315 & 1.3 & 0.178 & 4.941 & 19.6 & 48.8 \\
\hline DJ1 & 7148 & 1.03 & 0.293 & 3.947 & 18.5 & 44.4 \\
\hline DJ2 & 7083 & 1.04 & 0.250 & 2.336 & 18.2 & 44.4 \\
\hline DJ3 & 7040 & 1.43 & 0.315 & 6.055 & 16.8 & 47.7 \\
\hline DH1 & 6426 & 1.52 & 0.013 & 3.987 & 17.7 & 43.9 \\
\hline DH2 & 8037 & 1.83 & 0.036 & 2.801 & 16.5 & 44.1 \\
\hline DH3 & 7407 & 1.57 & 0.086 & 8.343 & 12.8 & 46.6 \\
\hline DM1 & 6939 & 1.53 & 0.009 & 1.022 & 18.3 & 45.3 \\
\hline DM2 & 7006 & 1.62 & 0.017 & 1.063 & 17.3 & 45.5 \\
\hline DM3 & 7701 & 1.66 & 0.068 & 2.430 & 16.2 & 48.2 \\
\hline
\end{tabular}




$\mathrm{Y}=\left|\begin{array}{llllll}8592 & 1.39 & 0.512 & 0.199 & 12.18 & 21.23 \\ 8673 & 1.21 & 1.903 & 0.330 & 13.24 & 20.34 \\ 8685 & 1.47 & 1.050 & 0.253 & 11.54 & 21.73 \\ 7406 & 1.35 & 0.347 & 0.095 & 9.43 & 22.72 \\ 7718 & 1.39 & 0.355 & 0.137 & 10.82 & 22.51\end{array}\right|$

Fig. 5. The initial matrix of each evaluation in tillering stage.

$\mathrm{R}=\left|\begin{array}{llllll}0.927 & 0.692 & 0.894 & 0.557 & 0.722 & 0.374 \\ 0.991 & 0.000 & 0.000 & 0.000 & 1.000 & 0.000 \\ 1.000 & 1.000 & 0.548 & 0.328 & 0.554 & 0.584 \\ 0.000 & 0.538 & 1.000 & 1.000 & 0.000 & 1.000 \\ 0.244 & 0.692 & 0.995 & 0.821 & 0.365 & 0.912\end{array}\right|$

Fig. 6. The standardized matrix of each evaluation in tillering stage.

$\mathrm{Z}=\left|\begin{array}{llllll}0.171 & 0.098 & 0.126 & 0.115 & 0.117 & 0.061 \\ 0.183 & 0.000 & 0.000 & 0.000 & 0.163 & 0.000 \\ 0.184 & 0.141 & 0.077 & 0.068 & 0.090 & 0.096 \\ 0.000 & 0.076 & 0.141 & 0.207 & 0.000 & 0.164 \\ 0.045 & 0.098 & 0.140 & 0.170 & 0.059 & 0.149\end{array}\right|$

Fig. 7. The value matrix of each evaluation in tillering stage.

better, then $x_{j}^{+}=\max z_{i j}, x_{j}^{-}=\max z_{i j^{\circ}}$ Or, $x_{j}^{+}=\min z_{i j}$, $x_{j}^{-}=\min z_{i j}$. At last, we can get: $x^{+}=(0.1844,0.1413$, $0.0000,0.0000,0.1626,0.1638) ; x_{j}^{-}=(0.0000,0.0000$, $0.1411,0.2068,0.0000,0.0000$ ).

Step 6: Calculate the Euclidean distance between each schemes and the ideal solution and negative ideal solution respectively.

Where,

$$
\mathrm{d}_{i}^{+}=\sqrt{\sum_{j=1}^{m}\left(z_{j}-x_{j}{ }^{+}\right)^{2}} \mathrm{~d}_{i}^{-}=\sqrt{\sum_{j=1}^{m}\left(z_{j}-x_{j}^{-}\right)^{2}}
$$

Step 7: Calculate the relative closeness degree between each scheme and the ideal solution, that is $S_{i}$ and $S_{i}=\frac{d_{i}^{-}}{\left(d_{i}^{+}+d_{i}^{-}\right)}$. The Euclidean distance closeness

Table 7. Distance and closeness of the 5 flooding treatments and ideal and negative ideal solution.

\begin{tabular}{|c|c|c|c|}
\hline Treatment & $d_{j}^{+}$ & $d_{j}^{-}$ & $S_{i}$ \\
\hline FT1 & 0.2094 & 0.2548 & 0.5489 \\
\hline FT2 & 0.2163 & 0.5371 & 0.7129 \\
\hline FT3 & 0.1431 & 0.3076 & 0.6824 \\
\hline FT4 & 0.3569 & 0.1806 & 0.3361 \\
\hline FT5 & 0.2842 & 0.1970 & 0.4094 \\
\hline
\end{tabular}

between the water level control schemes of the 5 flooded treatments and the ideal solutions and negative ideal solutions were listed in Table 7.

Step 8: Arrange $\mathrm{Si}$ in descending order, and the largest $\mathrm{Si}$ is the best (Table 8).

The water control schemes of different growth stages were listed in Table 9 in priority.

Thus, it can be seen that the water level control scheme of FT2, FJ2, FH1, FM2 treatments are the most advantageous to develop a comprehensive benefit, including the high-yield, saving-water, and pollution reduction. A conclusion about the best technical indicators of flooded rice in every growth stage was drawn in Table 10. As it was shown, leakage intensity should be controlled at $4 \mathrm{~mm} / \mathrm{d}$; for tillering stage,

Table 8 . The order of the relative closeness degree of the 5 flooding treatments.

\begin{tabular}{|c|c|c|}
\hline Sequence number & Treatment & $S_{i}$ \\
\hline 1 & FT2 & 0.7129 \\
\hline 2 & FT3 & 0.6824 \\
\hline 3 & FT1 & 0.5489 \\
\hline 4 & FT5 & 0.4094 \\
\hline 5 & FT4 & 0.3361 \\
\hline
\end{tabular}


Table 9. The water control programs priorities of different growth stages in flooding paddy field.

\begin{tabular}{|c|c|c|c|c|c|}
\hline Growth stage & \multicolumn{5}{|c|}{ Water control program priorities } \\
\hline Tillering stage & FT2 & FT3 & FT1 & FT5 & FT4 \\
\hline Jointing-booting stage & FJ2 & FJ3 & FJ1 & FJ5 & FJ4 \\
\hline Heading-flowering stage & FH1 & FH2 & FH3 & FH5 & FH4 \\
\hline Milkying stage & FM2 & FM1 & FM5 & FM4 & FM3 \\
\hline
\end{tabular}

Table 10. The best technical indicators of each growth stage in flooding paddy field.

\begin{tabular}{|c|c|c|c|c|}
\hline Growth stage & Tillering stage & Jointing-booting stage & Heading-flowering stage & Milkying stage \\
\hline Leakage $\left(\mathrm{mm} \mathrm{d}^{-1}\right)$ & 4 & 4 & 4 & 4 \\
\hline Flooding depth (mm) & 100 & 250 & 200 & 250 \\
\hline Flooding duration (d) & 5 & 5 & 7 & 5 \\
\hline
\end{tabular}

Table 11. The water control programs priorities of different growth stages in drought paddy field.

\begin{tabular}{|c|c|c|c|}
\hline Growth stage & \multicolumn{3}{|c|}{ Water control program priorities } \\
\hline Tillering stage & DT2 & DT3 & DT1 \\
\hline Jointing-booting stage & DJ3 & DJ2 & DH1 \\
\hline Heading-flowering stage & DH3 & DM2 & DM1 \\
\hline Milkying stage & DM3 & \\
\hline
\end{tabular}

Table 12.The best technical indicators of each growth stage in drought paddy field.

\begin{tabular}{|c|c|c|c|c|}
\hline Growth stage & Tillering stage & Jointing-booting stage & Heading-flowering stage & Milkying stage \\
\hline Drought depth $(\mathrm{mm})$ & -300 & -600 & -600 & -600 \\
\hline Drought duration (d) & 7 & 5 & 5 & 5 \\
\hline
\end{tabular}

flooding time lasted 5 days, suitable flooding depth was $100 \mathrm{~mm}$; for jointing-booting and milking stage, flooding time lasted 5 days, suitable flooding depth was $250 \mathrm{~mm}$; for heading-flowering stage, flooding time lasted 7 days, suitable flooding depth was $200 \mathrm{~mm}$.

\section{Water Level Program in Drought Paddy Field}

By calculation of entropy weight TOPSIS model, the water level control programs priorities of different growth stages were obtained in Table 11. It can be seen that the water level control scheme of FT2, FJ2, FH1 and FM2 treatments are the most advantageous to develop a comprehensive benefit at tillering, jointingbooting, heading-flowering, and milk stage, respectively.

The best technical indicators for drought rice in every growth stage were obtained in Table 12. As it was shown, for tillering stage, drought time lasted 7 days, and suitable drought depth was $100 \mathrm{~mm}$; while for the other stage, drought time lasted 5 days, and suitable drought depth was $600 \mathrm{~mm}$. It indicated that keeping a larger amount of leakage of paddy fields will promote the comprehensive benefit of water-saving, high yield, pollution-reduction, and fertilizer retention. Additionally, judging from the entire growth period, at the reproductive growth stage drought treatment was conducive to the comprehensive benefit, however, at tillering stage, where drought was not conducive to the benefit of rice.

\section{Conclusions}

The technology of controlled drainage in paddy field is a new direction of farmland drainage in future. In this paper, drought stress was used in rice growth stages as a kind of controlled drainage. From the above discussions, we can draw the following conclusions.

(1) The rice yield for drought treatment was $4.0 \%$ lower than that for flooding treatment, however, the WUE for controlled drainage was higher than that for conventional drainage. Rice yield was significantly different between flooding and drought treatments. 
In the early growth stage of rice, water supply was favorable for higher WUE, while it was opposite in the late growth stage.

(2) The content of $\mathrm{NH}_{4}^{+}-\mathrm{N}, \mathrm{NO}_{3}^{-}-\mathrm{N}$ and $\mathrm{TP}$ losses for drought treatment was $66.72 \%, 55.56 \%$ and $42.81 \%$ lower than that for flooding treatment, respectively. The main form of nitrogen loss was $\mathrm{NH}_{4}^{+}-\mathrm{N}$, while the proportion for $\mathrm{NO}_{3}^{-}-\mathrm{N}$ was small. With the same fertilizer level, the treatment for drought treatment could obviously reduce the $\mathrm{NH}_{4}^{+}-\mathrm{N}$ loss.

(3) Water condition had significant difference on soil RAP and RAN, while the RAP and RAN content in soil showed no significance under different water level control for both drought and flooding treatments. For the treatments under drought conditions, the soil available nitrogen and phosphorus content were extremely higher than that under flooding condition.

(4) Entropy weight TOPSIS model in different water control schemes determined the relative optimization water control scheme of each stage: for flooding field, leakage intensity should be controlled at $4 \mathrm{~mm} \mathrm{~d}^{-1}$, in tillering stage, flooding time lasted 5 days, suitable flooding depth was $100 \mathrm{~mm}$; in jointing-booting and milking stage, flooding time lasted 5 days, suitable flooding depth was $250 \mathrm{~mm}$; in heading-flowering stage, flooding time lasted 7 days, suitable flooding depth was $200 \mathrm{~mm}$; for drought paddy field, in tillering stage, drought time lasted 7 days, suitable drought depth was $100 \mathrm{~mm}$; in the other stage, drought time lasted 5 days, suitable drought depth was $600 \mathrm{~mm}$.

Lastly, owing to the lack of water resources, popularization of the study of technical indicators in paddy field has great significance in China.

\section{Acknowledgements}

The research was financially supported by the National Natural Science Fund (51409124, 51779093), Key Laboratory of Efficient Irrigation-Drainage and Agricultural Soil-Water Environment in Southern China (Hohai University), Ministry of Education (2017B20414-2), the High-level Talent Research Project of North China University of Water Resources and Electric Power (201705017), partly by National Key R\&D Program of China (2019YFC0408803), and Basic Public Welfare Research Project of Zhejiang Province (LGN20E090001).

\section{Conflicts of Interest}

The authors declare no conflicts of interest.

\section{References}

1. CHEN D., MIAO Z.M., JIANG K., CHEN J.R., SHEN Z.Y., QIU C.G. Nitrogen migration and fertilizer nitrogen utilization in paddy field under water saving irrigation
Journal of Jiangsu University(Natural Science Edition), 41 (1), 34, 2020.

2. BELDER P., BOUMAN B.A.M., CABANGON R., GUOAN L., QUILANG E.J.P., LI Y.H., SPIERTZ J.H.J., TUONG T.P. Effect of water-saving irrigation on rice yield and water use in typical lowland conditions in Asia. Agric Water Manage, 65, 193, 2004.

3. YANG J., GONG W., SHI S., DU L., SUN J., SON S.L. Estimation of nitrogen content based on fluorescence spectrum and principal component analysis in paddy rice. Plant Soil Environ., 62, 178, 2016.

4. YANG S.H., PENG S.Z., XU J.Z., HE Y.P., WANG Y.J. Effects of water saving irrigation and controlled release nitrogen fertilizer managements on nitrogen losses from paddy fields. Paddy Water Environ, 13 (1), 71, 2015.

5. JIANG L.H., XIE G.X., LIU Q., RONG X.M., XIANG X.Y., LI B. Effect of combined application of organic and inorganic fertilizers on soil microbial and carbon pool in double rice paddy field. Journal of Hunan Agricultural University (Natural Sciences), 44 (3), 295, 2018.

6. CHIRINDA N., CATER M.S., ALBERTB K.R., AMBUS P., OLESEN J.E., PORTER J.R., PETERSEN S.O. Emissions of nitrous oxide from arable organic and conventional cropping systems on two soil types. Agric Ecosyst Environ, 136, 199, 2010.

7. PENG S.Z., YANG S.H., XU J.Z., LUO Y.F., HOU H.J. Nitrogen and phosphorus leaching losses from paddy fields with different water and nitrogen managements. Paddy and water environment, 9 (3), 333, 2011.

8. SHAO D.H., LI Y., YANG P.F., GAO M.L. Analysis on nitrogen utilization and environmental effects under watersaving irrigation in paddy field. Journal of Hydraulic Engineering, 46 (2), 146, 2015.

9. WANG M., ZHOU W., GAO S.K., GUO R., YU S.E. Influence of alternative stress of drought and waterlogging on total phosphorus concentration in surface and subsurface water of paddy field. Journal of Hohai University (Natural Sciences), 45 (1), 63, 2017.

10. XIAO M.H., HU X.J., CHU L.L. Dynamic response of rice plant height growth to water level control on condition of drought-waterlogging alternating stress. Water-saving Irrigation, 9, 15, 2015.

11. GUO Y.F., PAN G.Q., WANG W.T., GUO E.W., LEI C.W., CHEN J. Comprehensive evaluation and analysis of water saving and high efficiency irrigation technology in Huang-huai Plain. Water-saving Irrigation, 5, 109, 2019.

12. LIU J., ZHANG J.Y., NING D.F., QIN A.Z., LIU Z.D., XIAO J.F., LIU J.M., ZHANG M.Z., DING P.F., SUN B. Comprehensive evaluation and optimization of sprinkler irrigation modes in a winter wheat-summer maize cropping system in Huang-huai well-irrigated area. Watersaving Irrigation, 11 (7), 1, 2019.

13. WANG Y.Y., YU S.E., XIAO M.H., HONG Y. Changes of nitrogen and phosphorus at sprouting and blooming stage and optimal drainage time in flooded paddy field. Journal of Hohai university (Natural Science Edition), 40 (3), 270, 2012.

14. XIAO M.H., YU S.E., WANG Y.Y., HUANG R. Nitrogen and phosphorus change and optimal drainage time of flooded paddy field based on environmental factors. Water science and engineering, 6 (2), 164, 2013.

15. XIN G.X., YANG C.X., YANG Q.Y., LI C.H., WEI C.F. Post-evaluation of well-facilitied capital farmland construction based on entropy weight method and 
improved TOPSIS model. Transactions of the Chinese Society of Agricultural Engineering, 33 (1), 238, 2017.

16. CAO R.Z., YU S.E., GAO S.K., GUO R., WANG M., ZHANG Y.D., WANG J. Evaluation of rice under alternating stress of drought and waterlogging based on entropy weight TOPSIS method. China Rural Water and Hydropower, 3, 45, 2017.

17. MIAO Z.M., LI J.C., CHEN D. Evaluation of water level management plan of winter wheat under waterlogging conditions based on entropy weighted TOPSIS model. Journal of Drainage and Irrigation Machinery Engineering, 36 (12), 1306, 2018.
18. CHEN K.W., YU S.E., LI Q.Q., ZHANG M.T., WANG Y., LIU Z.X. Simulation and evaluation of technical schemes for water-saving irrigation of rice in different hydrological years. Transactions of The Chinese Society of Agricultural Machinery, 50 (12), 268, 2019.

19. LV M., ZHANG Z.Y., KONG L.L., WANG K., JI Y.H. Controlled drinage in paddy fields based on the projection pursuit model. China Rural Water and Hydropower, 7, 31, 2011. 